\title{
ОЦЕНКА СУФФОЗИОННОЙ ОПАСНОСТИ ТЕРРИТОРИИ ПОС. САБЕТТА (ПОЛУОСТРОВ ЯМАЛ)
}

\author{
Строкова Людмила Александровна ${ }^{1}$, \\ sla@tpu.ru
}

\author{
Епифанова Екатерина Александровна', \\ epifanovaea@tpu.ru \\ 1 Национальный исследовательский Томский политехнический университет,
Россия, 634050, г. Томск, пр. Ленина, 30.
}

\begin{abstract}
Актуальность. Активное освоение полуострова Ямал приводит к трансфрормации геологической среды, часто сопровождающейся активизацией природных и техноприродных процессов. Многочисленные исследования посвящены описанию геокриологических процессов этого региона. В данной работе внимание уделяется особому слабоизученному процессу - сусффозии, на основе изучения гранулометрического состава песков, широко распространенных на территории Ямала.

Целью работы является оценка суфффозионной устойчивости грунтов и определение пространственных закономерностей распространения суффоозионно-опасных грунтов в районе населенного пункта Сабетта.

Методы. На первом этапе в ArcGIS составлены тематические карты фракторов, обусловливающих развитие сусрфозии. Было выбрано четыре фактора: уклон, кривизна поверхности, экспозиция склонов, геологическое строение территории. На втором этапе проведена обработка данных по гранулометрическому составу грунтов. Были определены: степень неоднородности гранулометрического состава, максимальный размер суфффозионных частии, степень суфффозионности грунтов основных стратиграфро-генетических комплексов, распространенных в районе. Оценка суфрфозионности песчаных грунтов выполнена по двум методикам. Составлена инвентаризационная карта проявлений суфффозионно-опасных песков. Заключительным этапом стало составление прогнозной карты восприимчивости территории к суффозии на основе изучения пространственных закономерностей распределения проявлений с учетом веса обусловливающих ее факторов.

Результаты работы и область их применения. Наиболее предрасположены к суффоозии зоны развития современных аллювиальных отложений, средней восприимчивостью характеризуется территория второй надпойменной террасы и с уклонами поверхности более 12 градусов, наименее предрасположена к суффрозии территория развития современных аллювиально-морских отложений. Полученные данные по степени суфффозионности песчаных грунтов рекомендуется использовать при проектировании инженерных сооружений. Используемую в работе технологию построения карт восприимчивости к суфрфозии рекомендуется опробовать при изучении геокриологических процессов, в первую очередь, бугров пучения.
\end{abstract}

\section{Ключевые слова:}

Суфффозия, опасность, гранулометрический состав, пески, степень неоднородности, восприимчивость, картографирование, метод соотношения частотностей.

\section{Введение}

Исследуемая площадка находится за полярным кругом и связана с освоением Южно-Тамбейского месторождения, производством сжиженного природного газа и его транспортировкой морским путем [1-3]. На территории широко развиты песчаные грунты, поэтому встал вопрос о наличии здесь такого процесса, как суффозия. В своей монографии В.П. Хоменко [4] приводит всеобъемлющую характеристику процесса суффозии как одного из наименее изученных опасных экзогенных геологических процессов. Автором под процессом суффозии понимает «разрушение и вынос потоком подземных вод отдельных компонентов и крупных масс дисперсных и сцементированных обломочных горных пород, в том числе слагающих структурные элементы скальных массивов» [4. С. 9]. Первое определение термина «суффозия», под которым понималось «механическое разрушение и растворение водопроницаемых пород подземными водами, сопровождающиеся выносом минерального вещества из этих пород», приводит А.П. Павлов [5]. В настоящее время существует более 15 разных определений суффозии [6-17], которые можно разделить на две группы: включающие или исключающие процесс растворения твердых компонентов горных пород.
Эту двусмысленность можно объяснить как сложностью самого процесса суффозии, так и недостаточностью всеобъемлющих исследований. Часто исследования сосредоточены лишь на одной стороне явления суффозии: либо химической, либо механической.

Суффозия приводит к появлению поверхностных и подземных эрозионных форм - проседанию вышележащей толщи и образованию западин - суффозионных воронок, блюдец, впадин, полостей, а также аккумулятивных форм - конусов выноса. Другим следствием суффозии может быть изменение гранулометрического состава пород как подверженных суффозии, так и являющихся фильтром для вынесенного материала, ухудшение прочностных и деформационных свойств [18-30].

Наиболее часто суффозия наблюдается на территориях распространения лёссов и лессовидных суглинков, в нижних частях склонов речных долин, часто по ходам роющих животных. Одним из необходимых условий суффозии является наличие в породе как крупных частиц, образующих неподвижный каркас, так и вымывающихся мелких. Вынос начинается лишь с определенных значений напора воды, ниже которых происходит только фильтрация [31-45]. 
Суффозионные провалы имеют как природное, так и техногенное происхождение. Большое значение имеет антропогенное воздействие, а именно сброс сточных вод, что усиливает развитие данного процесса. Техногенная суффозия встречается в местах утечек из водопроводных и канализационных сетей, барражного эффекта [45-55].

В соответствии с требованиями Стандарта комплексного развития территорий, отраслевых нормативных документов по инженерно-геологическим изысканиям для строительства [56-58] необходимо изучение опасных геологических и техноприродных процессов, к которым относится и суффозия, составление прогноза их развития и активизации, разработка рекомендаций для принятия решений по инженерной защите территории от опасных процессов.

Целью данной работы является определение пространственных закономерностей распространения суффозионно-опасных грунтов и построение прогнозной карты восприимчивости территории к проявлению суффозии.

\section{Характеристика инженерно-геологических условий территории}

Участок расположен за полярным кругом в границах полуострова Ямал и северной части Обской губы в зоне сплошной многолетней мерзлоты. Среднегодовая температура воздуха в районе минус $10,6^{\circ} \mathrm{C}$. Мощность мерзлой толщи $50 \ldots 360$ м. Глубина оттаивания почвы варьирует от 0,4 м для болот до 1,5 м на песчаных косах. Сильные ветры (более $15 \mathrm{~m} / \mathrm{c}$ ) регистрируются на протяжении всего года, чаще в зимний период. Количество осадков 314 мм/год, причем $40 \ldots 46 \%$ выпадает в виде снега или града. Часто бывают метели (в среднем более 100 дней в году).

В тектоническом отношении в основании Ямала залегает плита эпипалеозойской платформы с мезокайнозойским осадочным чехлом. Выступов кристаллического фундамента не наблюдается [59, 60].

В геологическом строении территории принимают участие палеозойские и мезозойско-кайнозойские осадочные породы, перекрытые четвертичными дисперсными грунтами мощностью 250...300 м. Голоценовые отложения представлены эоловыми, озерными, биогенными, аллювиальными и морскими разностями, плейстоценовые - морскими, лагунными, аллювиальными и ледниковыми.

В геоморфологическом отношении территория представляет плоскую низинную равнину с высотными отметками от 0 до 25 м с выделением второй террасы (14...20 м); первой озерно-аллювиальной террасой $(1 \ldots 7 \mathrm{M})$; современной лагунно-морской лайды $(0 \ldots 5$ м), в пределах которой различают: самую низкую часть - заболоченную впадину между первой террасой и литоральной полосой шириной $1 \ldots 2$ км, песчаную литоральную полосу в виде гребня шириной 200-800 м и намывные косы и пляжи, современные аллювиальные отложения рек (рис. 1).

Среди экзогенных процессов преобладают криогенные процессы (солифлюкция, пучение, морозобойное растрескивание, нивация, термоэрозия, тер- мокарст), подчиненное значение имеют литоральные, русловые и эоловые процессы.

Мерзлотные условия. Территория входит в Восточно-Ямальскую геокриологическую область, расположенную в северной части Западно-Сибирской плиты. Общие геокриологические условия характеризуются распространением ММП сливающегося типа. Мощность мерзлой толщи, определяемая по наличию текстурообразующего льда, составляет около 360 м. В пределах мелководья вдоль берега Обской губы существуют мягкие геокриологические условия, обусловленные отепляющим влиянием р. Оби. Установлено, что до глубины 50 м под Обской губой существует талик с почти вертикальной боковой границей.

Среднегодовые температуры пород на глубине нулевых годовых колебаний 8...15 м из-за неравномерного накопления снега, влияния поверхностных вод на различные элементы рельефа, а также результатов хозяйственной деятельности достигают значений минус $3 \ldots 7^{\circ} \mathrm{C}$. Наиболее высокие температуры - минус $3 . .4{ }^{\circ} \mathrm{C}$ - отмечаются на пляже, косах и в прибрежной полосе отливов-приливов Обской губы. На прирусловом валу температуры грунтов имеют значения минус $4 \ldots 6{ }^{\circ} \mathrm{C}$. Самые низкие значения температур отмечаются на неравномерно дренированных пойменных участках и составляют минус $5 \ldots 7^{\circ} \mathrm{C}$.

Значительная засоленность отложений морского генезиса способствует формированию в толще многолетнемерзлых грунтов талых прослоев (слоистой мерзлоты). Наиболее ярко криогенная слоистость выражена в зоне распространения криопегов, где включающие криопеги грунты при естественной температуре минус $4 \ldots 7{ }^{\circ} \mathrm{C}$ находятся в талом состоянии. Расчетная температура начала замерзания этих грунтов, характеризующихся высокой засоленностью, варьирует от минус 6 до минус $10^{\circ} \mathrm{C}$, что существенно ниже их естественной температуры.

На территории практически повсеместно развит сезонно-талый слой (СТС). Мощность СТС изменяется от 0,5 до 2 м. Наименышая мощность характерна для торфяников плоских заболоченных поверхностей междуречий. Для супесчано-суглинистых грунтов зоны сезонного оттаивания характерна высокая тиксотропность, а при промерзании - неравномерное площадное пучение. Наибольшими мощностями СТС характеризуются дренированные поверхности, где грунты СТС представлены песками и супесями, реже - суглинками с пониженной влажностью, а также косы и прирусловые валы.

В гидрогеологическом отношении район расположен в пределах Западносибирского артезианского бассейна, состоящего из верхней и нижней гидрогеологических зон, разделенных мощным туронскоэоценовым водоупором.

В структурно-гидрогеологическом плане исследуемая территория относится к Прикарскому бассейну стока подземных вод. По соотношению с многолетнемерзлыми породами (ММП) и положению в изучаемом разрезе до глубины 25 м выделяются надмерзлотные и внутримерзлотные воды. 

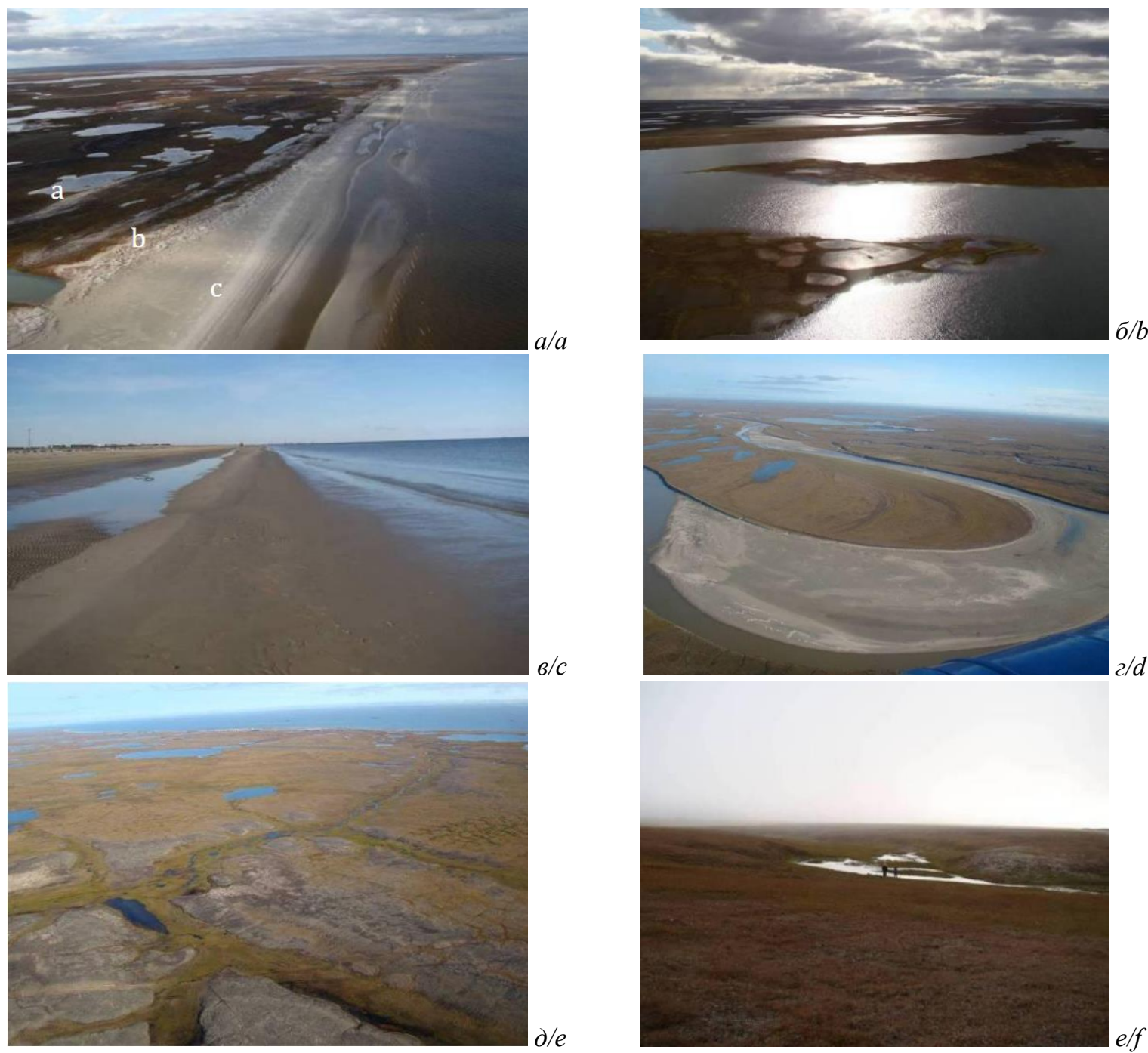

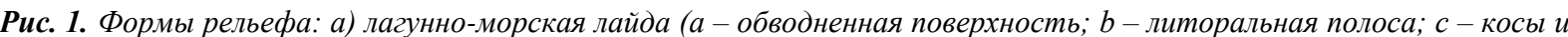
пляжи); б) обводненная поверхность лайды (зона, подверженная действию приливов); в) пляжи Обской губы вблизи п. Сабетта; г) пойма; д) современная аллювиально-морская терраса; е) вторая аллювиальная терраса и долина малой реки [3]

Fig. 1. Landforms: a) lagoon-sea laida ( $a$-watered surface; $b$ - littoral strip; $c$ - spit and beaches); $b$ ) watered surface of laida (zone exposed to tides); c) beaches of the Ob Bay near the settlement of Sabetta; d) floodplain; e) Holocene alluvial-sea terrace; $f$ ) second alluvial terrace and the valley of the small river [3]

Надмерзлотные воды сезонноталого слоя залегают на глубине $0,2 \ldots 1,5$ м от дневной поверхности, непосредственно над кровлей мерзлой толщи. Мощность водонасыщенного слоя не превышает $0,1 \ldots 0,4$ м. Основной источник питания надмерзлотных вод - летние атмосферные осадки и влага за счет таяния подземных льдов. Они находятся в безнапорном, часто застойном состоянии. Разгрузка надмерзлотных вод происходит во всех понижениях рельефа и приводит к значительному обводнению и заболачиванию депрессий рельефа. При зимнем промерзании эти воды приобретают напор, происходит криогенное пучение грунтов, и формируются бугры пучения. Воды этого слоя нейтральные, слабосолоноватые, очень жесткие, по составу сульфатно-хлоридные магниевые.

Засоленные отложения часто содержат линзы незамерзших отрицательно-температурных рассолов криопегов. Высокоминерализованные воды криопе- гов очень агрессивны по отношению к металлическим, бетонным и железобетонным конструкциям. Криопеги препятствуют смерзанию свай с грунтом и существенно снижают их несущую способность. Присутствие линз незамерзшей воды в толще ММП оказывает влияние на динамику температурного режима грунтов и их физико-механические свойства. Криопеги в толще засоленных ММП Ямала расположены на различной глубине, в виде линз различной мощности. В разрезе могут быть встречены несколько линз, различающиеся напорами и минерализацией воды, что свидетельствует об отсутствии гидравлической связи между ними.

В приурезовой зоне, на осушке, встречены межмерзлотные воды, залегающие на глубине 4,0-6,8 м. Это внутримерзлотные линзы и слои минерализованных подземных вод (криопэгов). 


\section{Методика выполнения работ}

Определение пространственных закономерностей распространения геологических опасностей выполнено по технологии построения карт восприимчивости (предрасположенности) территории к развитию экзогенных геологических процессов (ЭГП), описанной в работах [25-37]. Построение карт восприимчивости осуществляется в следующей последовательности. Вначале выполняется подготовка тематических слоев, таких как: карта проявления ЭГП (инвентаризационная карта); количества выпадающих осадков; литологии; геоморфологии; гидрогеологии; цифровой модели рельефа, с которой можно установить абсолютные отметки рельефа, угол склона, экспозиции и других факторов, обуславливающих возникновение ЭГП и интенсивности их развития. Поскольку значимость каждого фактора в зависимости от региональных геологических, морфометрических, климатических, техногенных условий в общей оценке разная, необходимо выполнять оценку веса каждого фактора. Такая оценка выполняется с помощью различных статистических и детерминированных подходов. В данной работе для определения веса каждого фактора использовался метод соотношения частотностей (frequency ratio, FR). Далее тематические карты умножаются на соответствующие веса каждого фактора и объединяются в одну средствами наложения, затем карта дифференцируется на категории с разной степенью восприимчивости в светофорной раскраске.

\section{Результаты}

\section{Подготовка тематических карт}

Для оценки суффозии была подготовлена серия тематических карт факторов их обусловливающих. Исходными данными для картографических построений послужили: цифровая модель рельефа (ЦМР) - снимок Landsat 8 (LC08_L1TP_164010_20190731_20200827_02_T1_refl.tif, рис. 2, a), загруженный с сайта USGS Earthexplorer, и производные из нее карты: уклонов, кривизны поверхности и экспозиции склонов, построенные с помощью «ArcGIS Desktop»; карты четвертичных образований листов R-42 и R-43, из фондов Всероссийского научно-исследовательского геологического института имени А. П. Карпинского [59, 60], карта распространения суффозионных песков, построенная авторами.

Стратиграфо-генетические комплексы пород один из наиболее важных параметров при изучении опасных геологических процессов, поскольку различные грунты имеют разную степень устойчивости к их развитию. Слой оцифрован по карте четвертичных образований листов R-42 и R43 масштаба $1: 1000000$ (рис. 2, б).

Кривизна склона (рис. 2, в). Значения кривизны характеризуют морфологию откосов. Кривизна влияет на гидрологическое состояние почвенного покрова. Потенциально после выпадения осадков почвенный покров на вогнутом склоне может содержать больше воды и удерживать ее дольше, чем на выпуклом склоне.
Уклон склона (рис. 2, г) является основным параметром при оценке территории. Градиент уклона контролирует скорость подземного стока после выпадения атмосферных осадков, скорость поверхностного стока и содержание влаги в грунтах. По мере увеличения уклона напряжение сдвига в рыхлом почвенном покрове обычно также увеличивается.

Экспозиция склона (рис. 2, д) определяет такие параметры, как воздействие солнечного света, осушающие ветры, осадки (степень насыщения) и неоднородности растительного покрова, которые могут влиять на активизацию ЭГП [25-27].

Карта проявлений суффозии (рис. 2, e). В основе этого слоя использовались данные расчетов по суффозионной опасности песков.

\section{Оценка суфффозионной опасности песков}

Для оценки суффозионной устойчивости дисперсных несвязных грунтов были собраны данные по гранулометрическому анализу песков из 70 скважин, пробуренных под строительство различных сооружений. Местоположение скважин показано на рис. 2, e. В разрезах встречено 95 слоев дисперсных несвязных грунтов, принадлежащих к четырем стратиграфогенетическим комплексам (СГК): современным аллювиальным отложениям пойменных террас и русла aIV, современным аллювиально-морским (дельтовым, пляжево-эстуарным) отложениям amH, верхнечетвертичным отложениям первой $\mathrm{a}^{1}$ III и второй $\mathrm{a}^{2}$ III надпойменных террас.

Многие исследователи (А.М. Дранников, В.С. Истомина, В.В. Пендин, С.В. Смолич и др.) считают, что суффозия развивается в породах, у которых степень неоднородности $(\mathrm{Cu})$ гранулометрического состава больше 20, а гидравлический градиент больше 1. Проверка этого условия по выбранным площадкам показала, что среди 95 разновидностей песчаных грунтов не встречено слоев, в которых $\mathrm{Cu}>20$. Для большей объективности было решено использовать и другие методы оценки суффозионности.

Вопросу оценки суффозионной устойчивости дисперсных несвязных грунтов много внимания уделялось во ВНИИГ имени В.Е. Веденеева [61-63]. В институте получены существенные практические рекомендации в области строительства гидротехнических сооружений, два из которых мы использовали при оценке суффозионной устойчивости несвязных грунтов.

Первый способ. Согласно руководству [61], без ухудшения прочности грунта могут быть вынесены самые мелкие частицы, количество которых не превышает 3-5 \% по массе, т. е. проверка суффозионной устойчивости песков осуществляется по условию:

$$
\begin{gathered}
d_{\max }^{c i} \leq d_{3} \ldots d_{5}, \\
d_{\max }^{c i}=0,77 d_{\max }^{0},
\end{gathered}
$$

где $d_{\max }^{c i}$ - максимальный размер частиц, которые могут быть вынесены фильтрационным потоком в результате суффозии; $d_{\max }^{0}$ - диаметр максимальных фильтрационных пор в грунте, определенный по формуле М.П. Павчича [14]: 

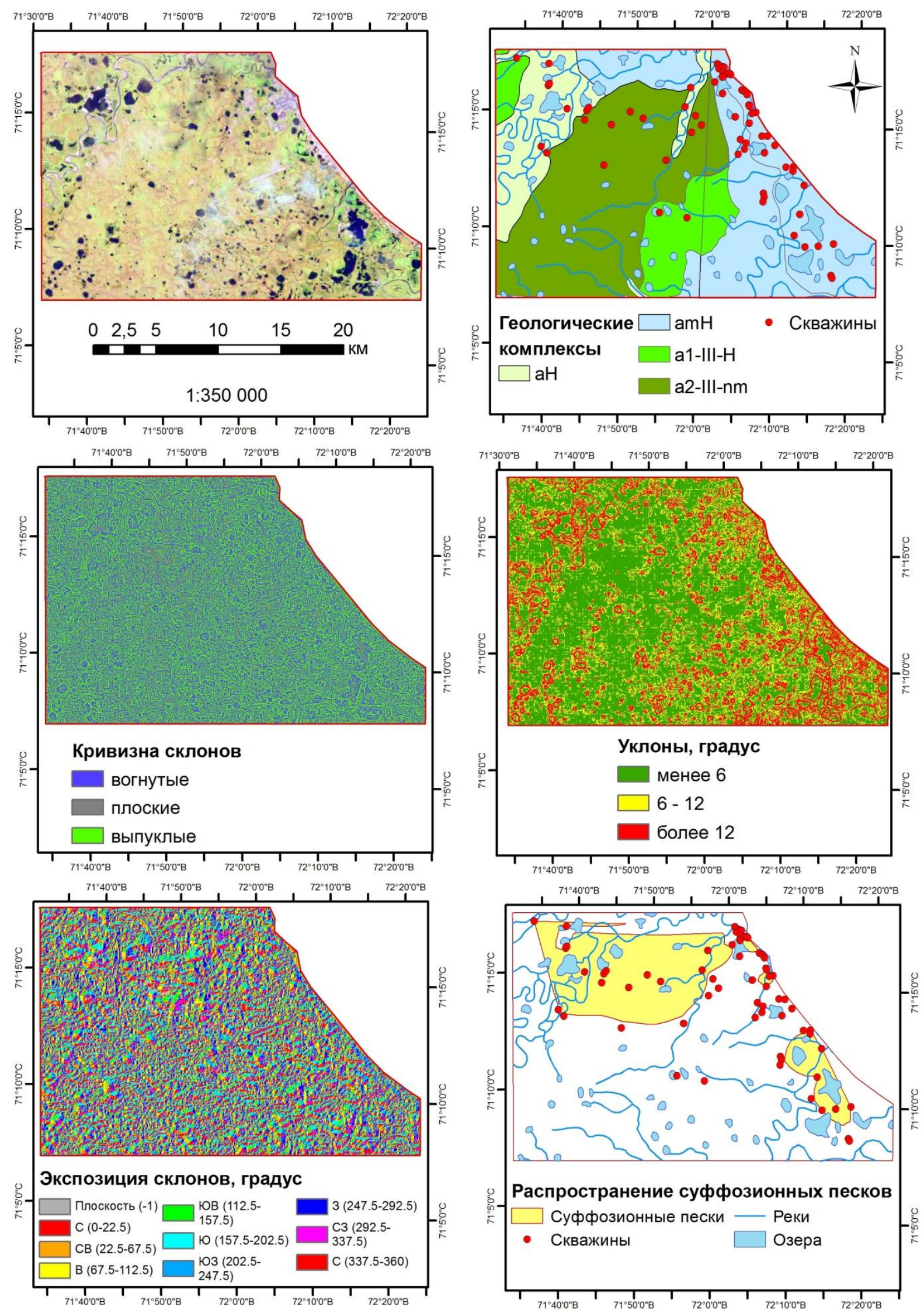

Pис. 2. Исходные слои для оценки суффозии

Fig. 2. Data layers for suffosion assessment 


$$
d_{\max }^{0}=0,455 k^{6} \sqrt{C_{u}} e d_{17},
$$

где $k$ - коэффициент неравномерности раскладки частиц в грунте или коэффициент локальности суффозии:

$$
\begin{gathered}
k=1+0,05 C_{\mathrm{u}}, \\
C_{\mathrm{u}}=d_{60} / d_{10},
\end{gathered}
$$

где $C_{\mathrm{u}}$ - степень неоднородности грунта; $d_{3}, d_{5}, d_{10}, d_{17}$, $d_{60}$ - диаметр частиц соответственно $3,5,10,17,60$ процентной обеспеченности (диаметры частиц, меньше которых в данном грунте содержится (по массе) соответственно $3,5,10,17,60 \%$ частиц); е коэффициент пористости.

Если условие не выполняется, то грунт считается суффозионным, из такого грунта могут выноситься все частицы с размером меньше или равным $d_{\max }^{c i}$. Максимально возможный процент выноса суффозионных частиц можно определить по значению $d_{\max }^{c i}$ на интегральной кривой гранулометрического состава. С.В. Щербаковым [64] предложен еще один параметр - степень суффозионности $\lambda_{1}$, который позволяет количественно оценивать интенсивность суффозионной опасности:

$$
\lambda_{1}=d_{3} \ldots d_{5}-d_{\max }^{c i} .
$$

Им предложено по значению $\lambda_{1}$ различать грунты: несуффозионные $(<0)$, слабосуффозионные $(0 \ldots 0,1)$, среднесуффозионные $(0,1 \ldots 0,2)$, сильносуффозионные $(>0,2)$. Проверка этого условия по выбранным площадкам показала, что среди 95 разновидностей песчаных грунтов встречен 91 слой, в котором $\lambda_{1}>0$, в т. ч. 80 - слабосуффозионных, 8 - среднесуффозионных и 3 - сильносуффозионных песков.
Второй способ. Критерий суффозионности записывается условием [62]

$$
\frac{d_{5}}{d_{17}} \geq K_{2}
$$

где

$$
K_{2}=\left(0,32+0,16 \cdot C_{u}\right) \cdot \sqrt[6]{C_{u}} \cdot \frac{e}{1-e} .
$$

Грунт считается несуффозионным, если условие выполняется. А.В. Шилова [65] вводит дополнительный параметр интенсивности суффозионной опасности - степень суффозионности $\lambda_{2}$ :

$$
\lambda_{2}=\frac{d_{5}}{d_{17}}-K_{2} .
$$

По значению $\lambda_{2}$ предложено различать грунты: несуффозионные $(<0)$, слабосуффозионные $(0 \ldots 100)$, среднесуффозионные $(100 \ldots 200)$, сильносуффозионные $(>200)$. Проверка этого условия по выбранным площадкам показала, что среди 95 разновидностей песчаных грунтов встречено 17 слабосуффозионных слоев, в которых $\lambda_{2}>0$. Расчет суффозионной устойчивости проводился по усредненным данным в пределах инженерно-геологических элементов, выделенных на площадках. Обобщенные значения результатов расчета суффозионной устойчивости представлены в табл. 1.

Из результатов, приведенных в табл. 1, следует, что встреченные в разрезах разности песчаных грунтов являются в основном слабосуффозионными. Кар-

\begin{tabular}{|c|c|c|c|c|c|c|c|c|c|c|c|}
\hline $\begin{array}{c}\text { СГК (количество определений) } \\
\text { Genetic types and age (number) }\end{array}$ & $\begin{array}{c}\text { Параметры } \\
\text { Characteristics } \\
\end{array}$ & $\mathrm{d}_{3}$ & $d_{5}$ & $\mathrm{~d}_{10}$ & $\mathrm{~d}_{17}$ & $\mathrm{~d}_{60}$ & $e$ & $\mathrm{Cu}$ & $\mathrm{d}^{\mathrm{ci}}{ }_{\text {max }}$ & $\lambda_{1}$ & $\lambda_{2}$ \\
\hline \multirow{4}{*}{$\begin{array}{l}\mathrm{amH} \\
(73)\end{array}$} & Среднее/Mean & 0,057 & 0,072 & 0,078 & 0,088 & 0,113 & 0,83 & 1,6 & 0,03 & 0,04 & $-2,23$ \\
\hline & $\begin{array}{l}\text { Стандартное отклонение } \\
\text { Standard deviation }\end{array}$ & 0,049 & 0,089 & 0,099 & 0,116 & 0,122 & 0,15 & 0,2 & 0,04 & 0,06 & 17,56 \\
\hline & Минимум/Minimum & 0,008 & 0,008 & 0,009 & 0,010 & 0,024 & 0,60 & 1,1 & 0,00 & $-0,02$ & $-82,14$ \\
\hline & Максимум/Maximum & 0,299 & 0,454 & 0,486 & 0,511 & 0,548 & 1,39 & 2,7 & 0,24 & 0,32 & 57,45 \\
\hline \multirow{4}{*}{$\begin{array}{c}\mathrm{aH} \\
(10)\end{array}$} & Среднее/Mean & 0,083 & 0,149 & 0,171 & 0,227 & 0,276 & 0,98 & 1,6 & 0,10 & 0,05 & 2,29 \\
\hline & $\begin{array}{c}\text { Стандартное отклонение } \\
\text { Standard deviation }\end{array}$ & 0,035 & 0,091 & 0,109 & 0,159 & 0,181 & $0,27 \mid$ & 0,1 & 0,08 & 0,04 & 4,07 \\
\hline & Минимум/Minimum & 0,039 & 0,039 & 0,041 & 0,044 & 0,068 & 0,69 & 1,5 & 0,01 & 0,02 & $-1,44$ \\
\hline & Максимум/Maximum & 0,120 & 0,237 & 0,310 & 0,417 & 0,478 & 1,40 & 1,9 & 0,20 & 0,12 & 10,46 \\
\hline \multirow{4}{*}{$\begin{array}{l}\mathrm{a}^{2} \mathrm{IIInm} \\
\quad(10)\end{array}$} & Среднее/Mean & 0,050 & 0,061 & 0,066 & 0,078 & 0,104 & 0,90 & 1,6 & 0,03 & 0,03 & 0,18 \\
\hline & $\begin{array}{c}\text { Стандартное отклонение } \\
\text { Standard deviation } \\
\end{array}$ & 0,025 & 0,058 & 0,065 & 0,096 & 0,106 & 0,22 & 0,1 & 0,03 & 0,03 & 4,14 \\
\hline & Минимум/Minimum & 0,035 & 0,036 & 0,038 & 0,042 & 0,065 & 0,63 & 1,5 & 0,01 & 0,01 & $-5,51$ \\
\hline & Максимум/Maximum & 0,121 & 0,225 & 0,249 & 0,350 & 0,405 & 1,31 & 1,8 & 0,11 & 0,12 & 7,27 \\
\hline \multirow{4}{*}{$\begin{array}{c}\mathrm{a}^{1} \mathrm{III} \\
(2)\end{array}$} & Среднее/Mean & 0,092 & 0,136 & 0,147 & 0,189 & 0,231 & 0,73 & 1,5 & 0,05 & 0,09 & $-1,34$ \\
\hline & $\begin{array}{c}\text { Стандартное отклонение } \\
\text { Standard Deviation } \\
\end{array}$ & 0,064 & 0,126 & 0,138 & 0,194 & 0,223 & 0,16 & $0,1 \mid$ & 0,05 & 0,08 & 1,47 \\
\hline & Минимум /Minimum & 0,046 & 0,047 & 0,049 & 0,051 & 0,073 & 0,61 & 1,5 & 0,02 & 0,03 & $-2,38$ \\
\hline & Максимум/Maximum & 0,137 & 0,225 & 0,244 & 0,326 & 0,389 & 0,85 & 1,6 & 0,08 & 0,14 & $-0,30$ \\
\hline
\end{tabular}
та распространения суффозионных песков построена по значению $\lambda_{2}$ с помощью инструмента интерполяции Spatial Analyst (ArcGIS), методом естественной окрестности (рис. 2, e).

Таблица 1. Оиенка суффозионной устойчивости песчаных грунтов

Table 1. Assessment of the suffosion stability of sandy soils

Определение веса факторов

Для определения веса каждого фактора методом соотношения частотностей (frequency ratio, FR) вначале были посчитаны площади классов каждого фактора и их доли (\%) от площади изучаемого участка.
Далее в пределах каждого класса определены площадь проявления ЭГП (в км² и \%), а также отношение \% площади проявления ЭГП к \% площади самого класса (вес FR). Вес каждого фактора и их классов приведены в табл. 2. 
Таблица 2. Результаты определения веса факторов развития суффозионной опасности грунтов

Table 2. Results of determining the weight of the suffosion-conditioning factors of soils

\begin{tabular}{|c|c|c|c|c|}
\hline $\begin{array}{c}\text { Слои данных } \\
\text { Data layers } \\
\end{array}$ & $\begin{array}{l}\text { Классы } \\
\text { Classes }\end{array}$ & $\begin{array}{c}\text { \% класса } \\
\% \text { of total area (a) }\end{array}$ & $\begin{array}{l}\% \text { суффозионных участков } \\
\% \text { of suffosion area (b) }\end{array}$ & $\begin{array}{c}\text { Bec по FR (b/a) } \\
\text { FR-weights }\end{array}$ \\
\hline \multirow{3}{*}{$\begin{array}{l}\text { Кривизна } \\
\text { склонов } \\
\text { Curvature }\end{array}$} & вогнутые/concave & 44,1 & 44,6 & 1,01 \\
\hline & плоские/flat & 8,1 & 8,0 & 0,99 \\
\hline & выпуклые/convex & 47,8 & 47,4 & 0,99 \\
\hline \multirow{10}{*}{$\begin{array}{c}\text { Экспозиция склонов, } \\
\text { градус } \\
\text { Slope aspect (degree) }\end{array}$} & плоские/flat & 1,6 & 1,8 & 1,10 \\
\hline & $\mathrm{C}(0-22,5)$ & 5,7 & 5,5 & 0,96 \\
\hline & CB $(22,5-67,5)$ & 12,6 & 12,4 & 0,98 \\
\hline & $\mathrm{B}(67,5-112,5)$ & 13,9 & 14,0 & 1,00 \\
\hline & ЮВ $(112,5-157,5)$ & 12,0 & 12,4 & 1,03 \\
\hline & Ю $(157,5-202,2)$ & 11,0 & 13,8 & 1,25 \\
\hline & Ю3 $(202,5-247,5)$ & 11,9 & 11,7 & 0,98 \\
\hline & $3(247,5-292,5)$ & 14,0 & 12,4 & 0,89 \\
\hline & C3 $(292,5-337,5)$ & 11,8 & 11,0 & 0,93 \\
\hline & $\mathrm{C}(337,5-360)$ & 5,4 & 5,1 & 0,95 \\
\hline \multirow{3}{*}{$\begin{array}{c}\text { Уклон, градус } \\
\text { Slope angle (degree) }\end{array}$} & $<6$ & 59,2 & 56,5 & 0,95 \\
\hline & $6-12$ & 23,1 & 24,4 & 1,06 \\
\hline & $>12$ & 17,7 & 19,1 & 1,08 \\
\hline \multirow{4}{*}{$\begin{array}{c}\text { Стратиграфо- } \\
\text { генетические } \\
\text { комплексы (СГК) } \\
\text { Genetic types and age }\end{array}$} & $\mathrm{aH}$ & 15,1 & 28,1 & 1,86 \\
\hline & $\mathrm{amH}$ & 35,1 & 29,2 & 0,83 \\
\hline & $\mathrm{a}^{1} \mathrm{III}$ & 11,3 & 0,72 & 0,06 \\
\hline & $\mathrm{a}^{2}$ IIInm & 38,5 & 41,9 & 1,09 \\
\hline
\end{tabular}

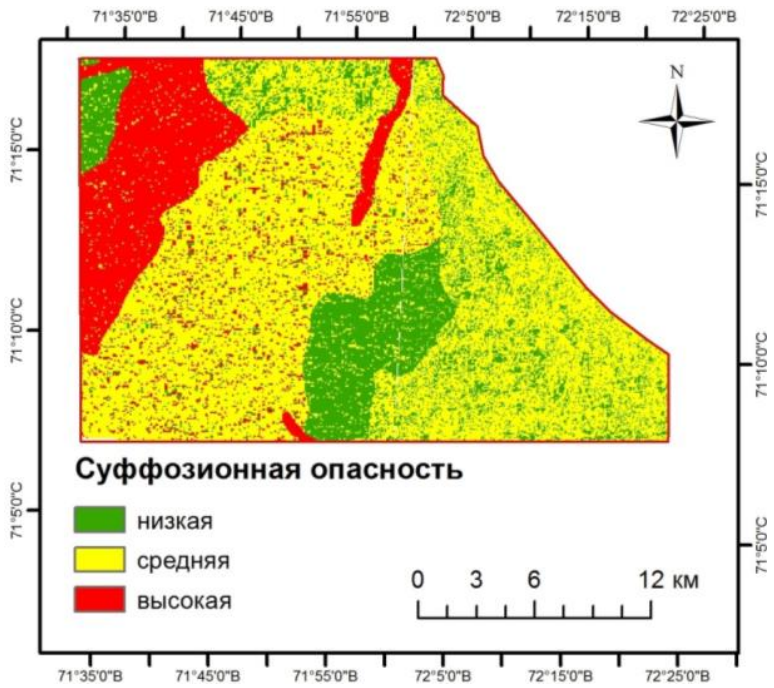

Puc. 3. Карта восприимчивости территории $к$ сурфозии с использованием FR метода

Fig. 3. Suffosion susceptibility map of the study area using the FR model

Как видно из табл. 2, самый высокий вес пораженности территории ЭГП $(\mathrm{FR}=1,86)$ имеет класс $\mathrm{aH}-$ площади развития современных аллювиальных отложений, на втором месте - склоны южной экспозиции $(\mathrm{FR}=1,25)$. Основная часть весов близка к единице, за исключением класса a III - первой надпойменной террасы $(\mathrm{FR}=0,06)$, вероятно, это обстоятельство можно объяснить малым количеством скважин на этой поверхности. Гранулометрический состав отложений первой террасы требует дальнейших исследований.

\section{Построение карты восприимчивости}

Тематические карты сложены с соответствующим весом каждого класса вышеперечисленных факторов в единую карту восприимчивости, которая расклас- сифицирована на три категории (низкой, средней, высокой степени) восприимчивости к суффозионной опасности в светофорной раскраске (рис. 3).

Зоны развития современных аллювиальных отложений характеризуются высокой степенью суффозионной опасности, средняя степень типична для территорий второй надпойменной террасы и с уклонами поверхности более 12 градусов, низкая степень восприимчивости к суффозии свойственна для территории развития современных аллювиально-морских отложений.

\section{Выводы}

1. На исследуемой территории получили развитие различные опасные геологические и геокриологические процессы, затрудняющие освоение территории.

2. Особое значение для данного района имеет наличие в разрезе дисперсных несвязных грунтов, склонных к развеванию, суффозии. Проведенная обработка данных по гранулометрическому составу песков позволила определить вероятные диаметры выносимых частичек, параметры интенсивности суффозионной опасности основных стратиграфо-генетических комплексов, распространенных в районе п. Сабетта. Выполнен анализ пространственных закономерностей распространения суффозионно-опасных песков района.

3. Используемую в работе технологию построения карт восприимчивости к суффозии рекомендуется опробовать при изучении геокриологических процессов района, в первую очередь, бугров пучения.

Исследование выполнено в Томском политехническом университете в рамках программы повышения конкурентоспособности Томского политехнического университета (средства ВИУ). 


\section{СПИСОК ЛИТЕРАТУРЫ}

1. Grosse G., Jones B. M. Spatial distribution of pingos in northern Asia // The Cryosphere. - 2011. - V. 5. - P. 13-33. URL: https:// doi.org/10.5194/tc-5-13-2011 (дата обращения 05.03.2021).

2. Дегазация земли в арктике: комплексные исследования распространения бугров пучения и термокарстовых озер с кратерами выбросов газа на полуострове Ямал / В.И. Богоявленский, О.С. Сизов, И.В. Богоявленский, Р.А. Никонов, Т.Н. Каргина // Арктика: экология и экономика. - 2019. № 4 (36). - C. 57-68. DOI: 10.25283/2223-4594-2019-4-52-68

3. Сенчяня И., Хэнкокс Д. Оценка воздействия на окружающую среду и социальную сферу проекта «Ямал СПГ». Заключительный отчет. Версия 5. - М.: ЭНВАЙРОН, 2014. - 953 с.

4. Хоменко В.П. Закономерности и прогноз суффозионных процессов. - М.: ГЕОС, 2003. - $216 \mathrm{c.}$

5. Павлов А.П. О рельефе равнин и его изменениях под влиянием работы подземных и поверхностных вод // Землеведение. 1898. - Т. 5. - № 3-4. - С. 91-147.

6. Аникеев А.В. Провалы и воронки оседания в карстовых районах: механизмы образования, прогноз и оценка риска. - М.: РУДН, 2017. - 328 с.

7. Бондарик Г.К., Пендин В.В., Ярг Л.А. Инженерная геодинамика. - М.: КДУ, 2007. - 327 с.

8. Буренкова В.В., Буренков П.М. Отечественный опыт оценки фильтрационной прочности несвязных грунтов тела плотины и основания // Природообустройство. - 2020. - № 4. - С. 84-91.

9. Дранников А.М. Инженерная геология. - Киев: Госстройиздат, 1964. - $256 \mathrm{c}$.

10. Дробинина Е.В., Катаев В.Н. Физические свойства песчаных и супесчаных грунтов покровной толщи в интегральной оценке суффозионной опасности территории в районах развития карбонатного карста // Геоинформатика. - 2017. - № 1. - С. 21-31.

11. Истомина В.С. Фильтрационная устойчивость грунтов. - М.: Госстройиздат, 1957. - 295 с.

12. Лаврусевич А.А., Хоменко В.П. Инженерная защита территорий, пораженных лессовым псевдокарстом // Вестник МГСУ. - 2012. - № 10. - С. 191-199.

13. Ломтадзе В.Д. Инженерная геология. Инженерная геодинамика. - Л.: Недра, 1977. - 479 с.

14. Павчич М.П. Способ определения несуффозионных гранулометрических составов грунта // Известия ВНИИГ. - 1961. T. 68. - С. 197-202.

15. Оценка суффозионной опасности площадки АЭС и ее окрестностей. Опасные для строительства геологические процессы / В.П. Пендин, А.С. Гусельцев, И.К. Фоменко, О.В. Зеркаль, О.Н. Сироткина // Сб. матер. Междунар. сем., посвящ. 70-летию д.г.-м.н. В.П. Хоменко. - М.: Изд-во МИСИ-МГСУ, 2019. - С. 22-29.

16. Смолич С.В., Смолич К.С. Количественная оценка суффозионной опасности песчаных грунтов // Сергеевские чтения Научное обоснование актуализации нормативных документов инженерно-геологических и инженерно-экологических изысканий. - М.: Российский университет дружбы народов (РУДН), 2010. - С. 176-181.

17. Хоменко В.П. Карстово-суффозионные процессы и их прогноз. - М.: Наука, 1986. - 98 с.

18. Engemoen W.O., Redlinger C.G. Internal erosion incidents at Bureau of Reclamation dams // Managing our Water Retention Systems: Proc. of $29^{\text {th }}$ USSD Annual Meeting and Conference. Nashville, TN, April 20-24, 2009. - Denver, CO: U.S. Society on Dams. 2009. - P. 731-745.

19. Erosion in geomechanics applied to dams and levees / Ed. by S. Bonelli. - Hoboken, NJ, USA: John Wiley \& Sons, Inc., 2013. $388 \mathrm{p}$.

20. Fannin R.J., Slangen P. On the distinct phenomena of suffusion and suffosion // Géotechnique Letters. - 2014. - V. 4. - Iss. 4. P. 289-294.

21. Glossary of geology / Eds. M. Gary, R. McAfee Jr, C.L. Wolf; with a foreword by I. Campbell. - Washington, D.C.: American Geological Institute, 1972. $-52 \mathrm{p}$.

22. Hutchinson J.N. Damage to slopes produced by seepage erosion in sands // Landslides and mudflows: reports of Alma Ata International Seminar. - Alma Ata, October 1981. - Moscow: Centre of International Projects, GKNT, 1982. - P. 250-265.
23. Kälin M. Hydraulic piping - theoretical and experimental findings // Canadian geotechnical journal. - 1977. - V. 14. - № 1. - P. 107-124.

24. Skempton A.W. Landmarks in early soil mechanics // The measurement, selection, and use of design parameters in geotechnical engineering: Proc. of $7^{\text {th }}$ European Conference on Soil Mechanics and Foundation Engineering. - Brighton, UK, September 1979. - London: British Geotechnical Society, 1979. V. 5. - P. 1-26.

25. Ghorbanzadeh O., Feizizadeh B., Blaschke T. An interval matrix method used to optimize the decision matrix in AHP technique for land subsidence susceptibility mapping. Environmental Earth Sciences. - 2018. - V. 77. - Article number 584.

26. Landslide susceptibility mapping for Austria using Geons and optimization with the Dempster-Shafer theory / T. Gudiyangada Nachappa, S. Tavakkoli Piralilou, O. Ghorbanzadeh, H. Shahabi, T. Blaschke // Applied Sciences. - 2019. - V. 9 (24). Article number 5393.

27. Comparison and validation of per-pixel and object-based approaches for landslide susceptibility mapping / T. Gudiyangada Nachappa, S. Kienberger, S.R. Meena, D. Hölbling, T. Blaschke // Geomatics, Natural Hazards and Risk. - 2020. - V. 11. - № 1. P. 572-600.

28. Estimating the quality of landslide susceptibility models / F. Guzzetti, P. Reichenbach, F. Ardizzone, M. Cardinali, M. Galli // Geomorphology. - 2006. - V. 81. - P. 166-184.

29. Ivanova E. Landslide susceptibility mapping using frequency ratio and Analytic Hierarchy Process (AHP): comparative study of two areas in Bulgaria // Proc. of the International Conference Analysis and Management of Changing Risk for Natural Hazards. - Padua, Italy, 18-19 November, 2014. - P. AP23-1-AP23-9.

30. Rasyid A.R., Bhandary N.P., Yatabe R. Performance of frequency ratio and logistic regression model in creating GIS based landslides susceptibility map at Lompobattang Mountain, Indonesia // Geoenvironmental Disasters. - 2016. - V. 3. Article number 19.

31. Optimizing the frequency ratio method for landslide susceptibility assessment: a case study of the Caiyuan Basin in the southeast mountainous area of China / Y.X. Zhang, H.X. Lan, L.P. Li, Y.M. Wu, J.H. Chen, N.M. Tian // Journal of Mountain Science. 2020. - V. 17. - Article number 2

32. Spatial distribution and susceptibility zoning of geohazards along the Silk Road, Xian-Lanzhou / J. Zhuang, J. Peng, X. Zhu, W. Li, P. Ma, T. Liu // Environmental Earth Sciences. - 2016. - V. 75. Article number 711 .

33. Wang M., Qiao J., He S. GIS-based earthquake-triggered landslide hazard zoning using contributing weight model // Journal of Mountain Science. - 2010. - V. 7. - P. 339-352. DOI: 10.1007/s11629-010-2054-7

34. Cheng J., Tao J.P. Fuzzy comprehensive evaluation of drought vulnerability based on the analytic hierarchy process - an empirical study from Xiaogan City in Hubei Province // Agriculture and Agricultural Science Procedia. - 2010. - V. 1. P. 126-135.

35. Classification of the type of eco-geological environment of a coal mine district: a case study of an ecologically fragile region in Western China / Z. Yang, W. Li, Y. Pei, W. Qiao, Y. Wu // Journal of Cleaner Production. - 2018. - V. 174. - P. 1513-1526.

36. Liu S., Li W. Indicators sensitivity analysis for environmental engineering geological patterns caused by underground coal mining with integrating variable weight theory and improved matter-element extension model // Science of the Total Environment. - 2019. - V. 686. - P. 606-618

37. Liu S., Li W., Wang Q. Zoning method for environmental engineering geological patterns in underground coal mining areas // Science of the Total Environment. - 2018. - V. 634. - P. 1064-1076.

38. Строкова Л.А., Ежкова А.В., Леонова А.В. Применение линеаментного анализа для оценки карстоопасности при проектировании магистрального газопровода в южной Якутии // Известия Томского политехнического университета. Инжиниринг георесурсов. - 2020. - Т. 331. - № 11. - С. 117-126.

39. Строкова Л.А. Районирование участков строительства прудовотстойников Эльгинского каменноугольного месторождения в Якутии» Якутии // Известия Томского политехнического университета. Инжиниринг георесурсов. - 2021. - Т. 332. - № 1. C. 97-106. 
40. Papin A.A., Sibin A.N. Simulation of the motion of a mixture of liquid and solid particles in porous media with regard to internal suffosion // Fluid Dynamics. - 2019. - V. 54 (4). - P. 520-534.

41. Wewer M., Aguilar-López J.P., Kok M., Bogaard T. A transient backward erosion piping model based on laminar flow transport equations // Computers and Geotechnics. - 2021. - V. 132. № 103992 .

42. A study of suffusion kinetics inspired from experimental data: comparison of three different approaches / A. Kodieh, R. Gelet, D. Marot, A.Z. Fino // Acta Geotechnica. - 2021. - V. 16 (2). P. 347-365.

43. Kanitz M., Grabe J. The influence of the void fraction on the particle migration: a coupled computational fluid dynamicsdiscrete element method study about drag force correlations // International Journal for Numerical and Analytical Methods in Geomechanics. - 2021. - V. 45 (1). - P. 45-63.

44. Prasomsri J., Takahashi A. The role of fines on internal instability and its impact on undrained mechanical response of gap-graded soils // Soils and Foundations. - 2020. - V. 60 (6). - P. 1468-1488

45. Строкова Л.А., Епифанова Е.А., Коржнева Т.Г. Численный анализ поведения основания опоры моста на старой железнодорожной линии // Известия Томского политехнического университета. Инжиниринг георесурсов. - 2017. - Т. 328. - № 5. C. $125-139$.

46. Епифанова Е.А., Строкова Л.А. Оценка деформаций исторического здания в Томске с помощью комплексного подхода, основанного на сочетании наземного лазерного сканирования и конечно-элементного моделирования // Известия Томского политехнического университета. Инжиниринг георесурсов. 2018. - T. 329. - № 5. - С. 27-41.

47. Епифанова Е.А., Строкова Л.А. Анализ деформаций прожекторной мачты при помощи наземного лазерного сканирования и метода конечных элементов // Известия Томского политехнического университета. Инжиниринг георесурсов. 2019. - T. 330 - № 5. - C. 7-17.

48. Опыт инженерно-геологического районирования по несущей способности грунтов промплощадки Эльгинского ГОК в Якутии / Л.А. Строкова, С.А. Дмитриева, Н.В. Осьмушкина, А.В. Осьмушкин // Известия Томского политехнического университета. Инжиниринг георесурсов. - 2019. - Т. 330. - № 2. C. $175-185$.

49. Strokova L. Recognition of geological processes in permafrost conditions // Bulletin of Engineering Geology and the Environment. - 2019. - V. 78 (8). - P. 5517-5530.

50. Фи Х.Т., Строкова Л.А. Типизация грунтовых толщ территории города Ханой (Вьетнам) при изучении оседания земной поверхности из-за извлечения подземных вод // Известия Томского политехнического университета. Инжиниринг георесурсов. - 2017. - Т. 328. - № 4. - С. 6-17.

51. Строкова Л.А., Галеева Э.И., Леонова А.В. Районирование инженерно-геокриологических условий трассы трубопровода на Восточно-Мессояхском нефтегазоконденсатном месторождении // Известия Томского политехнического университета. Инжиниринг георесурсов. - 2020. - Т. 331. - № 10. - С. 14-22.

52. Сахаровский А.В, Строкова Л.А. Определение устойчивости оползневого склона при проектировании моста через р. Пошнарку в Чувашии // Известия Томского политехнического университета. Инжиниринг георесурсов. - 2020. - Т. 331. № 1. - C. 125-134.

53. Строкова Л.А., Надеждина Ю.Ю. Типизация инженерногеологических условий территории трассы проектируемой железной дороги Элегест-Кызыл-Курагино // Известия Томского политехнического университета. Инжиниринг георесурсов. -2020 . - Т. 331. - № 2. - С. 64-77.

54. Строкова Л.А., Ежкова А.В., Леонова А.В. Применение линеаментного анализа для оценки карстоопасности при проектировании магистрального газопровода в южной Якутии // Известия Томского политехнического университета. Инжиниринг георесурсов. - 2020. - Т. 331. - № 11. - С. 117-126.

55. Оценка инженерно-геокриологических условий Берегового нефтегазоконденсатного месторождения / Л.А. Строкова, Д.В. Пургина, Э.И. Галеева, А.Н. Курчатова // Известия Томского политехнического университета. Инжиниринг георесурсов. -2018 . - Т. 329. - № 12. - С. 6-19.

56. СП 11-105-97. Инженерно-геологические изыскания для строительства. Ч. І. Общие правила производства работ. - М.: Госстрой России, 1997. -47 с.

57. СП 115.13330.2016. Геофизика опасных природных воздействий. - М.: Минстрой России, 2016. -49 с.

58. СП 116.13330.2012. Инженерная защита территорий, зданий и сооружений от опасных геологических процессов. - М.: Минрегион России, 2012. - 65 с.

59. Государственная геологическая карта Российской Федерации. Масштаб 1:1000000 (третье поколение). Серия ЗападноСибирская. Лист R-42 - п-ов Ямал. Объяснительная записка / М.А. Шишкин, Я.Э. Файбусович, С.И. Шкарубо, Д.В. Назаров. СПб.: Картографическая фабрика ВСЕГЕИ, 2015. - 366 с.

60. Государственная геологическая карта Российской Федерации. Масштаб 1:1000000 (третье поколение). Серия ЗападноСибирская. Лист R-43 - Обская губа. Объяснительная записка / Е.А. Лебедева, Я.Э. Файбусович, Д.В. Назаров, А.С. Воронин, Л.И. Рубин. - СПб.: Картфабрика ВСЕГЕИ, 2017. - 209 с.

61. Рекомендации по методике лабораторных испытаний грунтов на водопроницаемость суффозионную устойчивость: П 49-90. - Л.: ВНИИГ им. Б.Е. Веденеева, 1991. - 94 с.

62. Рекомендации по проектированию переходных зон каменноземляных плотин: П35-87. - Л.: ВНИИГ им. Б.Е. Веденеева, 1989. $-65 \mathrm{c}$

63. Рекомендации по проектированию обратных фильтров гидротехнических сооружений. П 56-90. СПб.: ВНИИГ, 1992. $110 \mathrm{c}$.

64. Щербаков С.В. Прогнозирование устойчивости сооружений в зависимости от суффозионности грунтов // Трофимуковские чтения-2013: матер. Всерос. молод. науч. конф. с участ. иностр. ученых. - Новосибирск, 8-14 сентября 2013. - С. 584-586.

65. Шилова А.В. Оценка суффозионной устойчивости и классифицирование грунтов на примере промплощадки // Сергеевские чтения. Юбилейная конференция, посвященная 100-летию со дня рождения академика Е.М. Сергеева. Материалы годичной сессии Научного совета РАН по проблемам геоэкологии, инженерной геологии и гидрогеологии. - М.: Российский университет дружбы народов, 2014. - С. 214-218.

Поступила 17.03.2021 г.

\section{Информация об авторах}

Строкова Л.А., доктор геолого-минералогических наук, профессор отделения геологии Инженерной школы природных ресурсов Национального исследовательского Томского политехнического университета.

Enuфанова E.A., кандидат геолого-минералогических наук инженер Научно-производственной лаборатории «Агробиофотоника» Инженерной школы новых производственных технологий Национального исследовательского Томского политехнического университета. 
UDK 624.131

\title{
ASSESSMENT OF SUFFOSION IN THE TERRITORY OF SETTLEMENT SABETTA, THE YAMAL PENINSULA
}

\author{
Lyudmila A. Strokova ${ }^{1}$, \\ sla@tpu.ru
}

\author{
Ekaterina A. Epifanova ${ }^{1}$, \\ epifanovaea@tpu.ru \\ 1 National Research Tomsk Polytechnic University, \\ 30, Lenin avenue, Tomsk, 634050, Russia.
}

\begin{abstract}
Relevance. The active development of the Yamal Peninsula leads to the transformation of the geological environment, often accompanied by the activation of natural and technological processes. Numerous studies are devoted to the description of geocryological processes in this region. In this work, we paid attention to a special poorly studied process - suffusion, based on the study of the grain size distribution of sands that are widely distributed in the territory of Yamal.

The main aim of the research is to assess the suffusion stability of soils and determine the spatial patterns of the distribution of suffusionhazardous soils in the area of the settlement Sabetta.

Methods. At the first stage, we compiled the thematic maps of the factors that determine the development of suffusion in ArcGIS. We chose four factors, namely: the slope, the curvature of the surface, the exposure of the slopes, and the geological structure of the territory. At the second stage, we processed the data on the grain size distribution of soils. The following factors were determined: uniformity coefficient, the maximum size of suffosion particles, and the degree of soil suffosion of the main stratigraphic-genetic complexes distributed in the area. The assessment of the suffusion of sandy soils was performed using two methods. An inventory map of the manifestations of suffusion-hazardous sands has been compiled. The final stage was the preparation of a forecast map of the territory's susceptibility to suffusion based on the study of spatial patterns of the distribution of its manifestations.

Results. The zones of development of modern alluvial deposits are the most prone to suffusion, the territory of the second abovefloodplain terrace is characterized by an average susceptibility and surface slopes of more than 12 degrees, the territory of development of modern alluvial-marine deposits is the least susceptible to suffusion. We recommended using the obtained data on the degree of suffosion of sandy and coarse-grained soils in the design of engineering structures. We recommended using the technology of susceptibility mapping in the study of geocryological processes, first of all, heaving mounds.
\end{abstract}

\section{Key word:}

Suffosion, danger, particle size distribution, sandy soils, uniformity coefficient, susceptibility, mapping, frequency ratio method.

The research was carried out at Tomsk Polytechnic University within the Program of Tomsk Polytechnic University Competitiveness Enhancement (VIU funds).

\section{REFERENCES}

1. Grosse G., Jones B. M. Spatial distribution of pingos in northern Asia. The Cryosphere, 2011, vol. 5, pp.13-33. Available at: https://doi.org/10.5194/tc-5-13-2011 (accessed 5 March 2021).

2. Bogoyavlensky V.I., Sizov O.S., Bogoyavlensky I.V., Nikonov R.A., Kargina T.N. Earth degassing in the Arctic: comprehensive studies of the distribution of frost mounds and thermokarst lakes with gas blowout craters on the Yamal Peninsula. Arctic: Ecology and Economy, 2019, no. 4 (36), pp. 52-68. In Rus. DOI: 10.25283/2223-4594-2019-4-52-68.

3. Senchyanya I., Khancoks J. Otsenka vozdeystviya na okruzhayush chuyu sredu $i$ sotsialnuyu sferu proekta «Jamal SPG» [Environmental and social impact assessment of the Yamal LNG project]. Final Report. Version 5. Moscow, ENVIRON Publ., 2014. 953 p.

4. Khomenko V.P. Zakonomernosti $i$ prognoz suffozionnykh protsessov [Regularities and forecasting of suffusion]. Moscow, GEOS Publ., 2003. 216 p.

5. Pavlov A.P. O relefe ravnin i ego izmeneniyakh pod vliyaniem raboty podzemnykh i poverhnostnykh vod [On the relief of the plains and its changes under the influence of the work of underground and surface waters]. Zemlevedenie, 1898, vol. 5, no. 3-4, pp. 91-147.

6. Anikeev A.V. Provaly i voronki osedaniya $v$ karstovykh rayonakh mekhanizmy obrazovaniya, prognoz $i$ otsenka riska [Collapse sinks and subsidences in karst areas: mechanisms, prediction, and risk estimation]. Moscow, RUDN University Publ., 2017. 328 p.

7. Bondarik G.K., Pendin V.V., Yarg L.A. Inzhenernaya geodinamika [Engineering geodynamics]. Moscow, KDU Publ., 2007. $327 \mathrm{p}$.
8. Burenkova V.V., Burenkov P.M. Domestic experience of assessing the filtration strength of non-cohesive soils of dam body and base. Environmental engineering, 2020, vol. 4, pp. 84-91. In Rus.

9. Drannikov A.M. Inzhenernaya geologiya [Engineering geology]. Kiev, Gosstroyizdat Publ., 1964. 256 p.

10. Drobinina E.V., Kataev V.N. Fizicheskie svoystva peschanykh i supeschanykh gruntov pokrovnoy tolshhi $\mathrm{v}$ integralnoy otsenke suffozionnoy opasnosti territorii $\mathrm{v}$ rayonakh razvitiya karbonatnogo karst [Physical properties of sandy and sandy loam soils of the cover layer in the integral assessment of the suffusion hazard of the territory in the areas of development of carbonate karst]. Geoinformatika, 2017, no. 1, pp. 21-31.

11. Istomina V.S. Filtratsionnaya ustoichivost gruntov [Filtration stability of soils]. Moscow, Gosstroyizdat Publ., 1957. 219 p.

12. Lavrusevich A.A., Khomenko V.P. Engineering protection of territories affected by loess pseudocarst. Bulletin of the MSU, 2012, no. 10, pp. 191-199. In Rus.

13. Lomtadze V.D. Inzhenernaya geologiya. Inzhenernaya geodinamika [Engineering geology. Engineering geodynamics]. Leningrad, Nedra Publ., 1977. 479 p.

14. Pavchich M.P. Sposob opredeleniya nesuffozionnykh granulometricheskikh sostavov grunta [Method for determining nondiffusion granulometric compositions of soil]. Izvestia VNIIG, 1961, vol. 68, pp. 197-202.

15. Pendin V.V., Guseltsev A.S., Fomenko I.K., Zerkal O.V., Sirotkina O.N. Otsenka suffozionnoy opasnosti ploshchadki AES i ee okrestnostei. Opasnye dlya stroitelstva geologicheskie protsessy [Assessment of suffusion hazard at a NPP site and its vicinity. 
Geological processes hazardous to construction]. Sbornik materialov Mezhdunarodnogo seminara, posvyashchennogo 70-letiyu V.P. Khomenko [Proc. Intern. Workshop dedicated to the $70^{\text {th }}$ birthday of Dr. Sc. V.P. Khomenko]. Moscow, MISI-MGSU Publ., 2019. pp. 22-29.

16. Smolich S.V., Smolich K.S. Kolichestvennaya otsenka suffozionnoy opasnosti peschanykh gruntov [Quantitative assessment of the suffusion hazard of sandy soils]. Sergeevskie Chteniya. Nauchnoe obosnovanie aktualizatsii normativnykh dokumentov inzhenernogeologicheskikh $i$ inzhenerno-ekologicheskikh izyskaniy [Sergeev Readings. Scientific substantiation of updating of normative documents of engineering-geological and engineering-ecological surveys]. Moscow, RUDN University Publ., 2010. pp. 176-181.

17. Khomenko V.P. Karstovo-suffozionnye protsessy i ikh prognoz [Karst-suffusion processes and their prognosis]. Moscow, Nauka Publ., 1986. 98 p.

18. Engemoen W.O., Redlinger C.G. Internal erosion incidents at Bureau of Reclamation dams. Managing our Water Retention Systems: Proc. of $29^{\text {th }}$ USSD Annual Meeting and Conference. Nashville, TN, April 20-24, 2009. Denver, CO, U.S. Society on Dams, 2009. pp. 731-745.

19. Erosion in geomechanics applied to dams and levees. Ed. by S. Bonelli. Hoboken, NJ, USA, John Wiley \& Sons, Inc., 2013. $388 \mathrm{p}$.

20. Fannin R.J., Slangen P. On the distinct phenomena of suffusion and suffusion. Géotechnique Letters, 2014, vol. 4, Iss. 4, pp. 289-294.

21. Glossary of geology. Eds. M. Gary, R. McAfee Jr, C.L. Wolf; with a foreword by Ian Campbell. Washington, D.C., American Geological Institute, $1972.52 \mathrm{p}$

22. Hutchinson J.N. Damage to slopes produced by seepage erosion in sands. Landslides and mudflows: reports of Alma Ata International Seminar, October 1981. Moscow, Centre of International Projects, GKNT, 1982. pp. 250-265.

23. Kälin M. Hydraulic piping - theoretical and experimental findings. Canadian geotechnical journal, 1977, vol. 14, no. 1, pp. 107-124.

24. Skempton A.W. Landmarks in early soil mechanics. The measurement, selection, and use of design parameters in geotechnical engineering: Proc. of $7^{\text {th }}$ European Conference on Soil Mechanics and Foundation Engineering. Brighton, UK, September 1979. London, British Geotechnical Society, 1979. Vol. 5, pp. 1-26.

25. Ghorbanzadeh O., Feizizadeh B., Blaschke T. An interval matrix method used to optimize the decision matrix in AHP technique for land subsidence susceptibility mapping. Environmental Earth Sciences, 2018, vol. 77, Article number 584.

26. Gudiyangada Nachappa T., Tavakkoli Piralilou S., Ghorbanzadeh O., Shahabi H., Blaschke T. Landslide susceptibility mapping for Austria using Geons and optimization with the Dempster-Shafer theory. Applied Science, 2019, vol. 9 (24), Article number 5393.

27. Gudiyangada Nachappa T., Kienberger S., Meena S.R., Hölbling D., Blaschke T. Comparison and validation of per-pixel and objectbased approaches for landslide susceptibility mapping. Geomatics, Natural Hazards and Risk, 2020, vol. 11, no. 1, pp. 572-600.

28. Guzzetti F., Reichenbach P., Ardizzone F., Cardinali M., Galli M. Estimating the quality of landslide susceptibility models. Geomorphology, 2006, vol. 81, pp. 166-184.

29. Ivanova E. Landslide susceptibility mapping using frequency ratio and Analytic Hierarchy Process (AHP): comparative study of two areas in Bulgaria. Proc. of the International Conference Analysis and Management of Changing Risk for Natural Hazards. Padua, Italy, 18-19 November, 2014. pp. AP23-1-AP23-9.

30. Rasyid A.R., Bhandary N.P., Yatabe R. Performance of frequency ratio and logistic regression model in creating GIS based landslides susceptibility map at Lompobattang Mountain, Indonesia. Geoenvironmental Disasters, 2016, vol. 3, Article number 19.

31. Zhang Y.X., Lan H.X., Li L.P., Wu Y.M, Chen J.H., Tian N.M. Optimizing the frequency ratio method for landslide susceptibility assessment: a case study of the Caiyuan Basin in the southeast mountainous area of China. Journal of Mountain Science, 2020, vol. 17 , Article number 2.

32. Zhuang J., Peng J., Zhu X., Li W., Ma P., Liu T. Spatial distribution and susceptibility zoning of geohazards along the Silk Road, Xian-Lanzhou. Environmental Earth Sciences, 2016, vol. 75, Article number 711.

33. Wang M., Qiao J., He S. GIS-based earthquake-triggered landslide hazard zoning using contributing weight model. Journal of Moun- tain Science, 2010, vol. 7, pp. 339-352. DOI: 10.1007/s11629010-2054-7.

34. Cheng J., Tao J.P. Fuzzy comprehensive evaluation of drought vulnerability based on the analytic hierarchy process - an empirical study from Xiaogan City in Hubei Province. Agriculture and Agricultural Science Procedia, 2010, vol. 1, pp. 126-135.

35. Yang Z., Li W., Pei Y., Qiao W., Wu Y. Classification of the type of eco-geological environment of a coalmine district: a case study of an ecologically fragile region in Western China. Journal of Cleaner Production, 2018, vol. 174, pp. 1513-1526.

36. Liu S., Li W. Indicators sensitivity analysis for environmental engineering geological patterns caused by underground coal mining with integrating variable weight theory and improved matterelement extension. Science of the Total Environment, 2019, vol. 686 , pp. 606-618.

37. Liu S., Li W., Wang Q. Zoning method for environmental engineering geological patterns in underground coal mining areas. Science of the Total Environment, 2018, vol. 634, pp. 1064-1076.

38. Strokova L.A., Ezhkova A.V., Leonova A.V. The application of lineament analysis to assess the karst hazard in the design of the main gas pipeline in South Yakutia. Bulletin of the Tomsk Polytechnic University. Geo Assets Engineering, 2020, vol. 331, no. 11 pp. 117-126. In Rus.

39. Strokova L.A. Zoning of construction sites of the settling ponds of the Elginsky coal Deposit in Yakutia. Bulletin of the Tomsk Polytechnic University. Geo Assets Engineering, 2021, vol. 332, no. 1, pp. 97-106. In Rus.

40. Papin A.A., Sibin A.N. Simulation of the motion of a mixture of liquid and solid particles in porous media with regard to internal suffosion. Fluid Dynamics, 2019, vol. 54, no. 4, pp. 520-534.

41. Wewer M., Aguilar-López J.P., Kok M., Bogaard T. A transient backward erosion piping model based on laminar flow transport equations. Computers and Geotechnics, 2021, vol. 132, no. 103992

42. Kodieh A., Gelet, R., Marot D., Fino A.Z. A study of suffusion kinetics inspired from experimental data: comparison of three different approaches. Acta Geotechnica, 2021, vol. 16, no. 2, pp. 347-365.

43. Kanitz M., Grabe J. The influence of the void fraction on the particle migration: a coupled computational fluid dynamics-discrete element method study about drag force correlations. International Journal for Numerical and Analytical Methods in Geomechanics, 2021, vol. 45, no. 1, pp. 45-63.

44. Prasomsri J., Takahashi A. The role of fines on internal instability and its impact on undrained mechanical response of gap-graded soils. Soils and Foundations, 2020, vol. 60, no. 6, pp. 1468-1488.

45. Strokova L.A., Epifanova E.A., Korzhneva T.G. Numerical analysis of bridge foundation behaviour on the old railway line. Bulletin of the Tomsk Polytechnic University. Geo Assets Engineering, 2017, vol. 328, no. 5, pp. 125-139. In Rus.

46. Epifanova E.A., Strokova L.A. Evaluation of deformation of a historic building in Tomsk by an integrated approach based on terrestrial laser scanner and finite element modeling. Bulletin of the Tomsk Polytechnic University, Geo Assets Engineering, 2018, vol. 329, no. 5, pp. 27-41. In Rus.

47. Epifanova E.A., Strokova L.A. Numerical analysis of deformations of the lighting mast by ground laser scanning and finite elements method. Bulletin of the Tomsk Polytechnic University. Geo Assets Engineering, 2019, vol. 330, no. 5, pp. 7-17. In Rus.

48. Strokova L.A., Dmitrieva S.A. Osmushkina N.V., Osmushkin A.V Experience of engineering-geological zoning on bearing capacity of soils of the industrial site of Elga coal-preparation plant in Yakutia. Bulletin of the Tomsk Polytechnic University. Geo Assets Engineering, 2019, vol. 330, no. 2, pp. 175-185. In Rus.

49. Strokova L. Recognition of geological processes in permafrost conditions. Bulletin of Engineering Geology and the Environment, 2019, vol. 78, no. 8, pp. 5517-5530

50. Phi H.T., Strokova L.A. Classification of soil types for Hanoi (Vietnam) when studying land subsidence at groundwater extraction. Bulletin of the Tomsk Polytechnic University. Geo Assets Engineering, 2017, vol. 328, no. 4, pp. 6-17. In Rus.

51. Strokova L.A., Galeeva E.I., Leonova A.V. Zoning of engineeringgeocryological conditions of the pipelines on VostochnoMessoyakhskoye field oil and gas condensate field. Bulletin of the Tomsk Polytechnic University. Geo Assets Engineering, 2020, vol. 331, no. 10, pp. 14-22. In Rus. 
52. Saharovskiy A.V., Strokova L.A. Determining landslide slope stability when designing a bridge over the river Poshnarka in the Chuvash Republic. Bulletin of the Tomsk Polytechnic University. Geo Assets Engineering, 2020, vol. 331, no. 1, pp. 125-134. In Rus.

53. Strokova L.A., Nadezhdina Yu.Yu. Typification of engineering and geological conditions of the territory of the route of the projected railway Elegest-Kyzyl-Kuragino. Bulletin of the Tomsk Po-lytechnic University. Geo Assets Engineering, 2020, vol. 331, no. 2, pp. 64-77. In Rus.

54. Strokova L.A., Ezhkova A.V., Leonova A.V. The application of lineament analysis to assess the karst hazard in the design of the main gas pipeline in South Yakutia. Bulletin of the Tomsk Polytechnic University. Geo Assets Engineering, 2020, vol. 331, no. 11 pp. 117-126. In Rus.

55. Strokova L.A., Purgina D.V., Galeeva E.I., Kurchatova A.N Evaluation of engineering-geocryological conditions of the Beregovoye oil and gas condensate field. Bulletin of the Tomsk Polytechnic University. Geo Assets Engineering, 2018, vol. 329, no. 12, pp. 6-19. In Rus.

56. SP 11-105-97. Inzhenerno-geologicheskie izyskaniya dlya stroitelstva. Ch. I. Obshchie pravila proizvodstva rabot [Engineering and geological surveys for construction. P. I. General rules for the production of works]. Moscow, Gosstroy of Russia Publ., 1997. $47 \mathrm{p}$.

57. SP 115.13330.2011. Geofizika opasnykh prirodnykh vozdeystviy [Geophysics of dangerous natural impacts]. Moscow, Minstroy of Russia Publ., 2016. 49 p.

58. SP 116.13330.2012. Inzhenernaya zashchita territoriy, zdaniy $i$ sooruzheniy ot opasnykh geologicheskikh protsessov [Engineering protection of territories, buildings and structures from dangerous geological processes]. Moscow, N.M. Gersevanov Research Institute of Regional Development Publ., 2012. 65 p.

59. Shishkin M.A., Faybusovich Ya.E., Shkarubo S.I., Nazarov D.V. Gosudarstvennaya geologicheskaya karta Rossiyskoy Federatsii. Masshtab 1:1000000 (trete pokolenie). Seriya Zapadno-Sibirskaya. List R-42 Yamal [State Geological Map of the Russian Federation. Scale 1:1000000 (third generation). West Siberian series. R-42 Yamal. Explanatory note]. St. Petersburg, Kartfabrika VSEGEI Publ., 2015. 366 p.

60. Lebedeva A., Faibusovich Ya.E., Nazarov D.V., Voronin A.S., Rubin L.I. Gosudarstvennaya geologicheskaya karta Rossiyskoy Federatsii. Masshtab 1:1000000 (trete pokolenie). Serija Zapad-
no-Sibirskaja. R-43-Obskaja guba [State Geological Map of the Russian Federation. Scale 1:1000000 (third generation). West Siberian series. Sheet R-43 - Ob bay. Explanatory note]. St. Petersburg, Kartfabrika VSEGEI Publ., 2017. 209 p.

61. Rekomendatsii po metodike laboratornykh ispytaniy gruntov na vodopronitsaemost suffozionnиyи ustoychivost [Recommendations on the methodology of laboratory tests of soils for water permeability and suffusion resistance]. P 49-90. Leningrad, VNIIG named after B.E. Vedeneev Publ., 1991. 94 p.

62. Rekomendatsii po proektirovaniyu perehodnykh zon kamennozemlyanykh plotin [Recommendations for the design of transition zones of stone-earth dams]. P35-87. Leningrad, VNIIG named after B.E. Vedeneev Publ., 1989. 65 p.

63. Rekomendatsii po proektirovaniyu obratnykh filtrov gidrotekhnicheskikh sooruzheniy [Recommendations for the design of reverse filters of hydraulic structures]. P. 56-90. St. Petersburg, VNIIG Publ., 1992. $110 \mathrm{p}$.

64. Shcherbakov S.V. Prognozirovanie ustoychivosti sooruzheny v zavisimosti ot suffozionnosti gruntov [Predicting the stability of structures depending on the soil suffusion]. Trofimukovskie chteniya-2013: Materialy Vserossiyskoy mo;odexhnoy nauchnoy konferentsii s uchastiem inostrannykh uchenykh [Trofimuk readings2013: Proc. All-Russian youth scientific conference with participation of foreign scientists]. Novosibirsk, September 8-14, 2013. pp. 584-586.

65. Shilova A.V. Otsenka suffozionnoy ustoychivosti i klassifitsirovanie gruntov na primere promploshchadki [Evaluation of suffusion stability and classification of soils on the example of an industrial site]. Sergeevskie chteniya. Yubileynaya konferentsiya, posvyashchennaya 100-letiyu so dnya rozhdeniya akademika E.M. Sergeeva. Materialy godichnoy sessii Nauchnogo soveta RAN po problemam geoekologii, inzhenernoy geologii i gidrogeologii [Sergeev Readings. Anniversary conference dedicated to the $100^{\text {th }}$ anniversary of the birth of Academician E.M. Sergeev. Proc. of the annual session of the Scientific Council of the Russian Academy of Sciences on Problems of Geoecology, Engineering Geology and Hydrogeology. Scientific Council of the Russian Academy of Sciences on Problems of Geoecology, Engineering Geology and Hydrogeology]. Moscow, RUDN University Publ., 2014. pp. 214-218.

Received: 17 March 2021.

\section{Information about the authors}

Lyudmila A. Strokova, Dr. Sc., professor, National Research Tomsk Polytechnic University.

Ekaterina A. Epifanova, Cand. Sc., engineer, National Research Tomsk Polytechnic University. 